\title{
Eco-physiology and Economics of Green Gram and Black Gram as Influenced by Sowing Dates in Tropical Summers
}

\author{
Sritama Biswas $^{1 *}$, Ananya Chakraborty ${ }^{1}$, Srijani Maji ${ }^{1}$ and Pintoo Bandopadhyay ${ }^{1}$ \\ Department of Agronomy, Bidhan Chandra KrishiViswavidyalaya, \\ Mohanpur-741252, Nadia, West Bengal, India \\ *Corresponding author
}

\section{A B S T R A C T}

Keywords

Green gram, Black gram, Sowing dates, Phosphate, Ecophysiological characters,

Equivalent yield, Harvest index, Economics

\section{Article Info}

Accepted:

15 August 2019

Available Online:

10 September 2019
Pulses constitute important protein supplements in diets for the resource poor tropics and in India. Green gram and black gram are popular summer pulses. Weather variations, either erratic or uncanny pre-monsoon rainfall, affect the summer crops and studies in optimum sowing window and crop performance comparison for black gram and green gram assumes importance. A field experiment was conducted during summer season of 2016 and 2017 at District Seed Farm, Bidhan Chandra KrishiViswavidyalaya, Nadia,West Bengal $\left(22^{\circ} 56^{\prime} \mathrm{N}, 88^{\circ} 32^{\prime} \mathrm{E}\right.$, and $\left.9.75 \mathrm{~m} \mathrm{AMSL}\right)$. Green gram $\left(\mathrm{C}_{1}\right)$ and black gram $\left(\mathrm{C}_{2}\right)$ and three sowing dates on $\mathrm{D}_{1}=14^{\text {th }}$ March, $\mathrm{D}_{2}=21^{\text {st }}$ March, $\mathrm{D}_{3}=28^{\text {th }}$ March are compounded as main-plot treatments taking two phosphate levels sub-plot treatments of $\mathrm{P}_{2} \mathrm{O}_{5} 40$ and 60 $\mathrm{kgha}^{-1}$ as which were replicated thrice in split plot design to find out the optimum sowing dates. Legumes are phosphophilic and higher phosphorus levels are introduced to understand the role of higher phosphate to offset any depletion of yield beyond optimum sowing dates. Green gram yield was significantly highest $\left(1012.42 \mathrm{kgha}^{-1}\right)$ on $21^{\text {st }}$ March sowing with $\mathrm{B}: \mathrm{C}$ ratio 2.26 and declines beyond while green gram equivalent yield of black gram was found to be $894.25 \mathrm{kgha}^{-1}$ on $28^{\text {th }}$ March sowing having $1.99 \mathrm{~B}: \mathrm{C}$ ratio. $60 \mathrm{kgha}^{-1}$ phosphate responded better for yield $\left(906.56 \mathrm{kgha}^{-1}\right)$. Green gram is recommended for $21^{\text {st }}$ March sowing and black gram after $28^{\text {th }}$ March with higher levels of phosphate.

\section{Introduction}

Pulses occupy a unique position in the Indian diet because of the cheapest sources of vegetable protein and other important nutrients such as $\mathrm{K}, \mathrm{Ca}, \mathrm{Mg}, \mathrm{Fe}, \mathrm{Zn}$ and vitamins viz., thiamine, riboflavin and niacin (Singh, 2017). They are consumed as staple food in combination with cereals, however they have limiting amount of essential amino acids such as methionine, tryptophan and cysteine (Tiwari and Singh, 2012). Pulse crops are also known to increase soil fertility and consequently the productivity of succeeding crop (Ali et al., 2012). India is the largest producer and consumer of pulses in the world accounting for about 29 per cent of the world area and 19 per cent of the world's production. But, pulse productivity was only $441 \mathrm{~kg} / \mathrm{ha}$ in 1950 that increased up to $689 \mathrm{~kg} / \mathrm{ha}$ during 
2011, registering $0.56 \%$ annual growth rate (Singh et al., 2015). In India, the domestic consumption of pulses was 186.5 lakh tonnes in the triennium ending 2010-11 against an average production of 158 lakh tonnes. The per capita per day availability of pulses in 1951 was $60.7 \mathrm{~g}$ that dwindled down to level of $35.4 \mathrm{~g}$ in the year 2010 .

The demand of pulse based diet has increased from 16.77 MT to 22 MT between 2007-08 and 2016-17. Among the pulse crops, Green gram (Vigna radiata (L.) Wilczek) and black gram (Vigna mungo (L.) Hepper) comprise $13 \%$ and $12 \%$ area of total pulse acreage respectively during 2010-2011 (Tiwari and Shivhare, 2016). These are drought resistant and can be grown as short duration summer pulses occupying same time in crop calendar year. But, the weather variability or climate change, has made the springs and summer more hot (Wang et al., 2015) nor-westers are irregular (Sadhukhan et al., 2000), and rainfall is erratic among other changes which forces us to revisit sowing dates in prevalent crops. Time of sowing time, as a non-monetary input, is the foremost important factor to obtain optimum yield from green gram (Dapaah et al., 2000).

Again, phosphorus nutrient is expensive to the farmer coupled with fixation issues and one of the major elements limiting the yield of grain legumes. It hastens and encourages the development of nitrogen fixing bacteria in the root nodules of pulse crops. Hence, pulses are phosphophilic, consequently respond significantly and phosphate levels may offset disadvantages or upscale advantages of biomass and yield in greengram and blackgram (Mohapatra et al., 1996; Singh et al., 2008). So, this makes them a perfect pair for comparative studies involving the dates of sowing and varying phosphate administration counting the concomitant changes in biomass, nodulation,eco-physiological characters (Ma et al., 2016), equivalent yields and harvest index for understanding resilience of crops along with pattern of sink development in the era of changed environmental exposures.

\section{Materials and Methods}

The field experiment was framed during spring-summer season of 2016 and 2017 at the District Seed Farm, AB Block, Bidhan Chandra Krishi Viswavidyalaya, Kalyani, Nadia, West Bengal having bearings of $22^{\circ} 56^{\prime}$ $\mathrm{N}$ latitude, $88^{\circ} 32^{\prime} \mathrm{E}$ longitude and at an altitude of $9.75 \mathrm{~m}$ above mean sea level, falling under New Alluvial Zone of West Bengal.

The experimental soil comes under the order of Entisol in the USDA modern taxonomical classification with sandy loam in texture consisting of $21.5 \%$ clay, $30 \%$ silt, and $48.5 \%$ sand with a bulk density of $1.46 \mathrm{Mgm}^{-1}$, almost neutral $\mathrm{pH}$ good drainage capacity and low available $\mathrm{N}$ and $\mathrm{P}$, and medium organic carbon as well as K status. Standard analytical procedures were followed for carrying out the chemical analysis of soil samples (Jackson, 1967).

The experiment was conducted in split plot design assigned in three replicates, where treatments were combination of (i) 2 crops viz. $\mathrm{C}_{1}=$ Greengram and $\mathrm{C}_{2}=$ Black gram and (ii) 3 sowing dates viz. $\mathrm{D}_{1}=14^{\text {th }}$ March, $\mathrm{D}_{2}=21^{\text {st }}$ March and $\mathrm{D}_{3}=28^{\text {th }}$ March compounded as the main factor while (iii) 2 phosphate levels viz. $\mathrm{P}_{1}=40 \mathrm{~kg} \mathrm{ha}^{-1}$ and $\mathrm{P}_{2}=60 \mathrm{~kg} \mathrm{ha}^{-1}$ were treated as sub plots. The doses of phosphorus were givenas per treatment through Single Super Phosphate. Basal application of uniform doseof20 $\mathrm{kg} \mathrm{N} / \mathrm{ha}$ was made through urea. Varieties taken were Meha (IPM-99-125) of green gram and black gram wasPant-U-31.

The leaf area index (LAI) was calculated by area-weight relationship method (Radford, 1967) using the following formula: 
$\mathrm{LAI}=$

Total leaf area for a given land area $\left(\mathrm{m}^{2}\right)$

\section{Land area considered $\left(\mathrm{m}^{2}\right)$}

The dry matter is further instrumental in calculating the stem mass fraction and root mass fraction (Poorter et al., 2012) where-

Root Mass Faction = Root dry mass/ Total dry mass, expressed in gg- $_{-}{ }^{1}$

Stem Mass Faction = Stem dry mass $/$ Total dry mass, expressed in $\mathrm{gg}^{-1}$

These are most lucid and important tools for interspecies growth comparison. Additionally for crop comparison, greengram equivalent yield of blackgram was calculated with the physical output of each crop and their price of output with Minimum Support Prices (MSP) of 2016-2017 given by CACP and economics were calculated for both the years to make the data conclusive. The formula used as follows: Green gram equivalent yield of black gram = (Price of black gram X Yield of black gram)/ Price of Green gram.

The statistical analysis of the data generated during investigation was carried out on computerized system was OP Stat Statistical Software Package for Agricultural Research (Sheoran et al., 1998).

\section{Results and Discussion}

\section{Above ground biomass}

Data presented in Table 1 showed that the mean above ground biomass was significantly superior in green gram (303.94 $\mathrm{gm}^{-2}$ ) over black gram $\left(243.62 \mathrm{gm}^{-2}\right)$ in pooled analysis as well as in both years. The dates of sowing had a significant impact on the above ground biomass. The $2^{\text {nd }}$ date of sowing and $3^{\text {rd }}$ date of sowing had values in statistical parity with marginal differences in between. The mean above ground biomass corresponding to $\mathrm{D}_{1}$ was statistically less in both years and in pooled analysis that enjoyed a value of 224.93 $\mathrm{gm}^{-2}$ with $\mathrm{D}_{2}$ registering $298.65 \mathrm{gm}^{-2}$ and $\mathrm{D}_{3}$ value closed with $297.76 \mathrm{gm}^{-2}$. Such close variation in the latter two dates may be due to the fact while green gram peaked up its growth in $2^{\text {nd }}$ date of sowing and the black gram had its peak on the $3^{\text {rd }}$ date sowing which is supplemented in the Table 2.

Legumes are phosphate responsive. Higher phosphate application improves upon vegetative and reproductive performance. In conformity, additional level of phosphate use resulted in significant increase in above ground biomass in the investigation. The mean above ground biomass recorded at $60 \mathrm{kgha}^{-1}$ was $295.32 \mathrm{gm}^{-2}$ which was significantly superior to its counterpart $\left(252.24 \mathrm{gm}^{-2}\right)$. The results corroborate with the findings of Rahaman et al., (2002).

\section{Root biomass}

The mean root biomass in Table 1 was also significantly greater in $\mathrm{C}_{1}\left(23.84 \mathrm{gm}^{-2}\right)$ over $\mathrm{C}_{2}$ $\left(18.73 \mathrm{gm}^{-2}\right)$ in pooled analysis and in both years. The averaged root biomass over two crops across the dates of sowing was also significant. The general trend showed the mean root biomass increased in $\mathrm{D}_{2}\left(22.94 \mathrm{gm}^{-2}\right)$ and $\mathrm{D}_{3}\left(23.98 \mathrm{gm}^{-2}\right)$ over the $\mathrm{D}_{1}\left(16.94 \mathrm{gm}^{-2}\right)$, having the $2^{\text {nd }}$ date and $3^{\text {rd }}$ date values in statistical parity.

Increased phosphorus application also resulted in significant improvement of mean root biomass in a very pronounced manner. The maximum root biomass was observed in 60 $\mathrm{kgha}^{-1}$ of phosphate use which was significantly superior $\left(22.98 \mathrm{gm}^{-2}\right)$ to lower regime of phosphate application $\left(19.60 \mathrm{gm}^{-2}\right)$ in pooled analysis. 


\section{Nodule dry weight}

Nodulation is the most important character of legume pulses and it contributes in many another way the physiology and growth in crop plants other than improving biological nitrogen fixation. The nodulation habit is expected to register its impact when legumes are grown successively and there is a compounding effect over the cropping seasons. Still nodulation habits are expected to vary over choice of species and also it may depend on root biomass, assuming soil conditions constant. Nodulation, being a root associated character, is influenced by below ground conditions and have less bearing on over ground phenotype unfolding which are more effected by light and duration. In Table 1 , the mean dry weight of nodules was significantly higher in green gram $\left(2.93 \mathrm{gm}^{-2}\right)$ over black gram $\left(2.67 \mathrm{gm}^{-2}\right)$ in both years and pooled analysis. The dates of sowing reflected that there had been significant variation in mean nodule weight in between $\mathrm{D}_{2}\left(2.92 \mathrm{gm}^{-2}\right)$ and $\mathrm{D}_{3}\left(2.89 \mathrm{gm}^{-2}\right)$ in pooled analysis and 2017 . The results corroborate with Okeleye and Okelana (1997).

The higher phosphate administration resulted in significant higher nodule dry weight (2.84 $\left.\mathrm{gm}^{-2}\right)$. Such reports of improved nodulation by addition of phosphate in legumes have been reported by Das et al., (2017).

\section{Leaf area index}

The leaf is the most important source organ of the plant in the source-sink relationship. In Table 3, the experimental findings revealed that green gram (4.71) had significantly higher LAI than black gram (3.80) in pooled analysis, and both years followed the same trend. But LAI is also a function of crop varieties in many publications (Samant et al., 2014) and such difference only in LAI is not always considered conclusive. $\mathrm{D}_{3}$ received higher values (4.36), being statistically at par with
$\mathrm{D}_{2}$ (4.34). LAI was significantly influenced by fertility levels. $60 \mathrm{kgha}^{-1}$ phosphate applications resulted into higher LAI (4.319).

\section{Stem mass fraction}

Green gram and black gram belong to the same genus. Poorter, 2012 proposed interspecies comparison through some variables which are biomass related and ratios of different growth parameters. Table 3 reveal that the stem mass fraction was highest in case of green gram and superior too with a value of 0.449 over black gram (0.376) in pooled analysis. The $2^{\text {nd }}(0.426)$ and $3^{\text {rd }}$ sowings (0.427) scored better values and was significant over $\mathrm{D}_{1}(0.385)$. Phosphate had no effect on stem mass fraction.

\section{Root mass fraction}

Root mass fractions were also not significant for pooled analysis and both the years. This supports that root is a function of not only the species under study but also the rhizosphere which affects and influences the comparing crop species in a similar manner. So root study and RMF may behave differently with other physio-ecological conditions. Phosphate application also behaved non-significant on root mass fraction.

\section{Equivalent yield}

Table 4 shows that the yield of green gram is significantly superior $\left(962.72 \mathrm{~kg} \mathrm{ha}^{-1}\right)$ over black gram $\left(719.80 \mathrm{kgha}^{-1}\right) .2^{\text {nd }}$ sowing date $\left(910.73 \mathrm{~kg} \mathrm{ha}^{-1)}\right.$ also performed significantly superior to $1^{\text {st }}$ date $\left(731.28 \mathrm{kgha}^{-1}\right)$ and was at par with the $3^{\text {rd }}$ sowing date $\left(881.76 \mathrm{~kg} \mathrm{ha}^{-1}\right)$. Crop and date of sowing effect was significant with $\mathrm{C}_{1} \mathrm{D}_{2}$ scoring the maximum having yield of $1094.24 \mathrm{kgha}^{-1}$ and $\mathrm{C}_{2} \mathrm{D}_{3}$ having $828.95 \mathrm{~kg}$ $\mathrm{ha}^{-1}$. The regular trend of black gram having rising trend of significantly higher yields till the last sowing and green gram arresting rise till the $2^{\text {nd }}$ sowing was upheld (Table 5). 
Table.1 Above ground biomass, root biomass and nodule dry weight of greengram and blackgram as influenced by sowing dates and phosphate levels

\begin{tabular}{|c|c|c|c|c|c|c|c|c|c|}
\hline \multirow[t]{2}{*}{ Treatment } & \multicolumn{3}{|c|}{$\begin{array}{c}\text { Above ground } \\
\text { biomass at harvest }\left(\mathrm{gm}^{-2}\right)\end{array}$} & \multicolumn{3}{|c|}{$\begin{array}{c}\text { Root biomass } \\
\text { at harvest }\left(\mathrm{gm}^{-2}\right)\end{array}$} & \multicolumn{3}{|c|}{$\begin{array}{c}\text { Nodule } \\
\text { dry weight }\left(\mathrm{gm}^{-2}\right)\end{array}$} \\
\hline & 2016 & 2017 & Pooled & 2016 & 2017 & Pooled & 2016 & 2017 & Pooled \\
\hline \multicolumn{10}{|c|}{ Crops } \\
\hline $\operatorname{Greengram}\left(\mathbf{C}_{1}\right)$ & 296.88 & 311.01 & 303.94 & 23.47 & 22.22 & 23.84 & 2.96 & 2.91 & 2.93 \\
\hline $\operatorname{Blackgram}\left(\mathbf{C}_{2}\right)$ & 237.75 & 249.49 & 243.62 & 18.68 & 18.79 & 18.73 & 2.69 & 2.65 & 2.67 \\
\hline $\operatorname{SEm}( \pm)$ & 8.77 & 4.74 & 6.19 & 0.73 & 0.05 & 0.05 & 0.01 & 0.003 & 0.005 \\
\hline C.D. (0.05) & 27.62 & 14.95 & 19.50 & 2.32 & 0.18 & 0.18 & 0.03 & 0.011 & 0.015 \\
\hline \multicolumn{10}{|c|}{ Sowing Dates } \\
\hline $14^{\text {th }} \operatorname{March}\left(D_{1}\right)$ & 220.22 & 229.64 & 224.93 & 17.00 & 16.88 & 16.94 & 2.61 & 2.57 & 2.59 \\
\hline $21^{\text {st }}$ March $\left(D_{2}\right)$ & 290.32 & 306.99 & 298.65 & 22.67 & 23.22 & 22.94 & 2.92 & 2.87 & 2.89 \\
\hline $28^{\text {th }} \operatorname{March}\left(\mathrm{D}_{3}\right)$ & 291.40 & 304.12 & 297.76 & 23.55 & 24.41 & 23.98 & 2.94 & 2.89 & 2.92 \\
\hline $\operatorname{SEm}( \pm)$ & 10.74 & 5.81 & 7.58 & 0.90 & 0.07 & 0.07 & 0.01 & 0.004 & 0.006 \\
\hline C.D. (0.05) & 33.83 & 18.31 & 23.88 & 2.84 & 0.22 & 0.22 & 0.04 & 0.013 & 0.019 \\
\hline \multicolumn{10}{|c|}{ Phosphate levels } \\
\hline $40 \mathrm{kgha}^{-1}\left(P_{1}\right)$ & 247.27 & 257.21 & 252.24 & 19.48 & 19.72 & 19.60 & 2.79 & 2.74 & 2.76 \\
\hline $60 \mathrm{kgha}^{-1}\left(\mathrm{P}_{2}\right)$ & 287.36 & 303.29 & 295.32 & 22.67 & 23.29 & 22.98 & 2.86 & 2.82 & 2.84 \\
\hline $\operatorname{SEm}( \pm)$ & 4.32 & 5.11 & 3.55 & 0.31 & 0.02 & 0.02 & 0.01 & 0.001 & 0.005 \\
\hline C.D. (0.05) & 13.31 & 15.74 & 10.96 & 0.98 & 0.07 & 0.07 & 0.03 & 0.002 & 0.014 \\
\hline
\end{tabular}

Table.2 Interaction effect of crops (C), dates of sowing (D) and phosphate levels (P) on above ground biomass $\left(\mathrm{gm}^{-2}\right)$

\begin{tabular}{|c|c|c|c|}
\hline \multicolumn{4}{|c|}{$\mathbf{C} \mathbf{X} \mathbf{D} \mathbf{~ P}$} \\
\hline & $\mathbf{2 0 1 6}$ & $\mathbf{2 0 1 7}$ & Pooled \\
\hline $\mathbf{C}_{\mathbf{1}} \mathbf{D}_{\mathbf{1}} \mathbf{P}_{\mathbf{1}}$ & 228.05 & 237.17 & 232.61 \\
\hline $\mathbf{C}_{\mathbf{1}} \mathbf{D}_{\mathbf{1}} \mathbf{P}_{\mathbf{2}}$ & 260.61 & 278.85 & 269.74 \\
\hline $\mathbf{C}_{\mathbf{1}} \mathbf{D}_{\mathbf{2}} \mathbf{P}_{\mathbf{1}}$ & 295.57 & 309.46 & 302.52 \\
\hline $\mathbf{C}_{\mathbf{1}} \mathbf{D}_{\mathbf{2}} \mathbf{P}_{\mathbf{2}}$ & 377.33 & 399.18 & 388.26 \\
\hline $\mathbf{C}_{\mathbf{1}} \mathbf{D}_{\mathbf{3}} \mathbf{P}_{\mathbf{1}}$ & 272.32 & 285.37 & 278.85 \\
\hline $\mathbf{C}_{\mathbf{1}} \mathbf{D}_{\mathbf{3}} \mathbf{P}_{\mathbf{2}}$ & 347.41 & 356.03 & 351.72 \\
\hline $\mathbf{C}_{\mathbf{2}} \mathbf{D}_{\mathbf{1}} \mathbf{P}_{\mathbf{1}}$ & 184.78 & 185.32 & 185.05 \\
\hline $\mathbf{C}_{\mathbf{2}} \mathbf{D}_{\mathbf{1}} \mathbf{P}_{\mathbf{2}}$ & 207.46 & 217.21 & 212.34 \\
\hline $\mathbf{C}_{\mathbf{2}} \mathbf{D}_{\mathbf{2}} \mathbf{P}_{\mathbf{1}}$ & 235.02 & 248.29 & 241.66 \\
\hline $\mathbf{C}_{\mathbf{2}} \mathbf{D}_{\mathbf{2}} \mathbf{P}_{\mathbf{2}}$ & 253.35 & 271.05 & 262.20 \\
\hline $\mathbf{C}_{\mathbf{2}} \mathbf{D}_{\mathbf{3}} \mathbf{P}_{\mathbf{1}}$ & 267.87 & 377.67 & 272.77 \\
\hline $\mathbf{C}_{\mathbf{2}} \mathbf{D}_{\mathbf{3}} \mathbf{P}_{\mathbf{2}}$ & 278.00 & 297.43 & 287.72 \\
\hline $\mathbf{S E m}_{\mathbf{(} \mathbf{(})}$ & 10.58 & 12.51 & 8.71 \\
\hline $\mathbf{C . D}_{\mathbf{D}} \mathbf{( \mathbf { 0 } \mathbf { 0 } \mathbf { 0 5 } )}$ & $\mathrm{NS}$ & $\mathrm{NS}$ & $\mathrm{NS}$ \\
\hline
\end{tabular}


Table.3 Effects of sowing dates and phosphate regimes on LAI and eco-physiological characters of green gram and black gram at harvest

\begin{tabular}{|c|c|c|c|c|c|c|c|c|c|}
\hline \multirow[t]{2}{*}{ Treatment } & \multicolumn{3}{|c|}{ Leaf Area Index } & \multicolumn{3}{|c|}{ Stem Mass Fraction $\left(\mathrm{gg}^{-1}\right)$} & \multicolumn{3}{|c|}{ Root Mass Fraction $\left(\mathrm{gg}^{-1}\right)$} \\
\hline & 2016 & 2017 & Pooled & 2016 & 2017 & Pooled & 2016 & 2017 & Pooled \\
\hline \multicolumn{10}{|c|}{ Crops } \\
\hline $\operatorname{Green} \operatorname{gram}\left(\mathrm{C}_{1}\right)$ & 4.612 & 4.823 & 4.71 & 0.434 & 0.464 & 0.449 & 0.073 & 0.069 & 0.072 \\
\hline Black gram $\left(C_{2}\right)$ & 3.728 & 3.872 & 3.80 & 0.364 & 0.389 & 0.376 & 0.074 & 0.067 & 0.070 \\
\hline $\operatorname{SEm}( \pm)$ & 0.029 & 0.011 & 0.016 & 0.010 & 0.011 & 0.010 & 0.003 & 0.001 & 0.001 \\
\hline C.D. (0.05) & 0.091 & 0.035 & 0.051 & 0.032 & 0.034 & 0.033 & NS & NS & NS \\
\hline \multicolumn{10}{|c|}{ Sowing Dates } \\
\hline $14^{\text {th }} \operatorname{March}\left(D_{1}\right)$ & 3.987 & 4.158 & 4.07 & 0.372 & 0.398 & 0.385 & 0.072 & 0.065 & 0.068 \\
\hline $21^{\text {st }} \operatorname{March}\left(D_{2}\right)$ & 4.254 & 4.433 & 4.34 & 0.412 & 0.440 & 0.426 & 0.073 & 0.068 & 0.070 \\
\hline $28^{\text {th }} \operatorname{March}\left(D_{3}\right)$ & 4.269 & 4.452 & 4.36 & 0.413 & 0.441 & 0.427 & 0.076 & 0.071 & 0.073 \\
\hline $\operatorname{SEm}( \pm)$ & 0.035 & 0.013 & 0.020 & 0.012 & 0.013 & 0.013 & 0.003 & 0.001 & 0.002 \\
\hline C.D. $(0.05)$ & 0.112 & 0.042 & 0.063 & NS & NS & NS & NS & 0.004 & NS \\
\hline \multicolumn{10}{|c|}{ Phosphate levels } \\
\hline $40 \mathrm{kgha}^{-1}\left(\mathbf{P}_{1}\right)$ & 4.100 & 4.277 & 4.185 & 0.402 & 0.429 & 0.416 & 0.073 & 0.067 & 0.070 \\
\hline $60 \operatorname{kgha}^{-1}\left(P_{2}\right)$ & 4.420 & 4.423 & 4.319 & 0.396 & 0.423 & 0.410 & 0.074 & 0.069 & 0.071 \\
\hline $\operatorname{SEm}( \pm)$ & 0.023 & 0.002 & 0.011 & 0.006 & 0.006 & 0.006 & 0.001 & 0.001 & 0.001 \\
\hline C.D. (0.05) & 0.071 & 0.007 & 0.035 & NS & NS & NS & NS & NS & NS \\
\hline
\end{tabular}

Table.4 Effects of sowing dates and phosphate regimes on yield equivalents and harvest index of green gram and black gram

\begin{tabular}{|c|c|c|c|c|c|c|}
\hline \multirow[t]{2}{*}{ Treatment } & \multicolumn{3}{|c|}{ Equivalent yield $\left(\mathrm{kgha}^{-1}\right)$} & \multicolumn{3}{|c|}{ Harvest Index \% } \\
\hline & 2016 & 2017 & Pooled & 2016 & 2017 & Pooled \\
\hline \multicolumn{7}{|c|}{ Crops } \\
\hline $\operatorname{Green} \operatorname{gram}\left(\mathbf{C}_{1}\right)$ & 941.43 & 984.01 & 962.72 & 33.11 & 34.60 & 33.86 \\
\hline $\operatorname{Black} \operatorname{gram}\left(\mathrm{C}_{2}\right)$ & 716.08 & 723.51 & 719.80 & 39.87 & 42.04 & 40.96 \\
\hline $\operatorname{SEm}( \pm)$ & 14.9 & 3.39 & 7.89 & 0.67 & 0.76 & 0.65 \\
\hline C.D. (0.05) & 46.95 & 10.71 & 24.85 & 2.12 & 2.41 & 2.05 \\
\hline \multicolumn{7}{|c|}{ Sowing Dates } \\
\hline $14^{\text {th }} \operatorname{March}\left(D_{1}\right)$ & 720.38 & 742.19 & 731.28 & 34.46 & 36.63 & 35.55 \\
\hline $21^{\text {st }} \operatorname{March}\left(D_{2}\right)$ & 896.54 & 924.92 & 910.73 & 37.12 & 39.19 & 38.15 \\
\hline $28^{\text {th }} \operatorname{March}\left(D_{3}\right)$ & 869.35 & 894.17 & 881.76 & 37.88 & 39.13 & 38.51 \\
\hline $\operatorname{SEm}( \pm)$ & 18.25 & 4.16 & 9.66 & 0.82 & 0.94 & 0.80 \\
\hline C.D. (0.05) & 57.5 & 13.14 & 30.44 & 2.59 & NS & 2.51 \\
\hline \multicolumn{7}{|c|}{ Phosphate levels } \\
\hline $40 \operatorname{kgha}^{-1}\left(P_{1}\right)$ & 764.44 & 787.47 & 775.96 & 35.26 & 37.04 & 36.15 \\
\hline $60 \operatorname{kgha}^{-1}\left(\mathbf{P}_{2}\right)$ & 893.07 & 920.05 & 906.56 & 37.72 & 39.60 & 38.66 \\
\hline $\operatorname{SEm}( \pm)$ & 1.73 & 1.27 & 1.42 & 0.52 & 0.51 & 0.46 \\
\hline C.D. (0.05) & 5.35 & 3.93 & 4.37 & 1.60 & 1.56 & 1.42 \\
\hline
\end{tabular}


Table.5 Interaction effect of crops, dates of sowing and phosphate levels on yield equivalent $\left(\mathrm{kgha}^{-1}\right)$ as pooled analysis

\begin{tabular}{|c|c|c|c|c|c|c|c|c|c|}
\hline & $\mathbf{C}_{1} \mathbf{D}_{1}$ & $\mathbf{C}_{1} \mathbf{D}_{2}$ & $C_{1} D_{3}$ & $\mathbf{C}_{2} \mathbf{D}_{1}$ & $\mathbf{C}_{2} \mathbf{D}_{2}$ & $\mathbf{C}_{2} \mathbf{D}_{3}$ & Mean & $\operatorname{SEm}( \pm)$ & C.D. (0.05) \\
\hline $40 \operatorname{kgha}^{-1}\left(P_{1}\right)$ & 789.41 & 1026.46 & 842.32 & 561.78 & 657.73 & $\begin{array}{c}778.0 \\
7\end{array}$ & $\begin{array}{c}775.9 \\
6\end{array}$ & \multirow[t]{3}{*}{3.47} & \multirow[t]{3}{*}{10.71} \\
\hline $60 \mathrm{kgha}^{-1}\left(\mathrm{P}_{2}\right)$ & 894.23 & 1211.51 & $\begin{array}{c}1012.4 \\
2\end{array}$ & 679.74 & 747.24 & $\begin{array}{c}894.2 \\
5\end{array}$ & $\begin{array}{c}906.5 \\
6\end{array}$ & & \\
\hline Mean & 841.82 & 1118.98 & 927.37 & 620.76 & 702.48 & $\begin{array}{c}836.1 \\
6\end{array}$ & $\begin{array}{c}841.2 \\
6\end{array}$ & & \\
\hline
\end{tabular}

Table.6 Economics of black gram and green gram across sowing dates and varying phosphate levels as pooled analysis

\begin{tabular}{|l|c|c|c|}
\hline Treatments & Gross return (Rs.) & Net return (Rs.) & BCR \\
\hline $\mathbf{C}_{\mathbf{1}} \mathbf{D}_{\mathbf{1}} \mathbf{P}_{\mathbf{1}}$ & 41246.53 & 13814.53 & 1.50 \\
\hline $\mathbf{C}_{\mathbf{1}} \mathbf{D}_{\mathbf{1}} \mathbf{P}_{\mathbf{2}}$ & 46723.27 & 18661.27 & 1.67 \\
\hline $\mathbf{C}_{\mathbf{1}} \mathbf{D}_{\mathbf{2}} \mathbf{P}_{\mathbf{1}}$ & 53632.52 & 26200.52 & 1.96 \\
\hline $\mathbf{C}_{\mathbf{1}} \mathbf{D}_{\mathbf{2}} \mathbf{P}_{\mathbf{2}}$ & 63301.50 & 35239.50 & 2.26 \\
\hline $\mathbf{C}_{\mathbf{1}} \mathbf{D}_{\mathbf{3}} \mathbf{P}_{\mathbf{1}}$ & 44011.09 & 16579.09 & 1.60 \\
\hline $\mathbf{C}_{\mathbf{1}} \mathbf{D}_{\mathbf{3}} \mathbf{P}_{\mathbf{2}}$ & 52898.90 & 24836.90 & 1.89 \\
\hline $\mathbf{C}_{\mathbf{2}} \mathbf{D}_{\mathbf{1}} \mathbf{P}_{\mathbf{1}}$ & 29352.77 & 6489.77 & 1.28 \\
\hline $\mathbf{C}_{\mathbf{2}} \mathbf{D}_{\mathbf{1}} \mathbf{P}_{\mathbf{2}}$ & 35516.55 & 12023.55 & 1.51 \\
\hline $\mathbf{C}_{\mathbf{2}} \mathbf{D}_{\mathbf{2}} \mathbf{P}_{\mathbf{1}}$ & 34366.33 & 11503.33 & 1.50 \\
\hline $\mathbf{C}_{\mathbf{2}} \mathbf{D}_{\mathbf{2}} \mathbf{P}_{\mathbf{2}}$ & 39043.13 & 15550.13 & 1.66 \\
\hline $\mathbf{C}_{\mathbf{2}} \mathbf{D}_{\mathbf{3}} \mathbf{P}_{\mathbf{1}}$ & 40654.11 & 17791.11 & 1.78 \\
\hline $\mathbf{C}_{\mathbf{2}} \mathbf{D}_{\mathbf{3}} \mathbf{P}_{\mathbf{2}}$ & 46724.51 & 23231.51 & 1.99 \\
\hline
\end{tabular}

Reports showed that delayed sowing after March and early sowing before February reduce yield of summer green gram (Chovatia et al., 1993). Elevated phosphate level was significant with $906.56 \mathrm{~kg} \mathrm{ha}^{-1}$ equivalent yield in pooled analysis following the similar trend in both years. Similar result was obtained by Khan et al., (1999).

\section{Harvest index}

Harvest Index was higher in black gram $(40.96 \%)$ compared to that of green gram $(33.86 \%)$. D2 and D3 are statistical at par in both years and pooled analysis and were significantly greater than $\mathrm{D}_{1}$. Harvest index (38.66\%) behaved significantly with higher level of phosphate administration. 


\section{Interaction effects}

Interaction effect of crops dates of sowing and phosphate levels on above ground biomass as pooled analysis performed to be nonsignificant (Table 2) but it was significant for equivalent yield (Table 5). For yield equivalents, $\mathrm{C}_{1} \mathrm{D}_{2} \mathrm{P}_{2}$ scored the maximum yield of $1012.42 \mathrm{kgha}^{-1}$ and the black gram treatment $\mathrm{C}_{2} \mathrm{D}_{3} \mathrm{P}_{2}$ had $894.25 \mathrm{kgha}^{-1}$ equivalent yield. Rest were not significant. The interaction (Table 5) of main plot and sub plot treatments show that higher level of phosphate in black gram was contributory in bringing about more green gram equivalent yield $\left(894.25 \mathrm{kgha}^{-1}\right)$ over green gram yield $\left(842.32 \mathrm{kgha}^{-1}\right)$ with recommended dose of phosphate $\left(40 \mathrm{kgha}^{-1}\right)$. This helps us to understand that if sowing is delayed black gram performs better than green gram with elevated phosphate levels and the trend of economics (Table 6) also hold the same finding.

\section{Economics}

In Table 6, highest gross return was yielded by green gram sown on second date and having elevated phosphate levels (Rs. $63,301.50 /-)$, followed by the same crop grown in the second sowing date even with lower phosphate application (Rs. 53,632.52/-. This further indicates that the yield of the legumes is more of a function of environments than that of inputs mobilized. The maximum gross return from black gram was registered at the $3^{\text {rd }}$ sowing date (Rs. 46,724.51/-) with elevated phosphate level. The corresponding net returns were Rs. 35,239.50/-, Rs.26,200.52/- and Rs. 23231.51/- respectively. The Benefit: Cost ratio was maximum for $\mathrm{C}_{1} \mathrm{D}_{2} \mathrm{P}_{2}$ (2.26) followed by $\mathrm{C}_{2} \mathrm{D}_{3} \mathrm{P}_{2}$ with a ratio of 1.99 . The data suggests that in the third date or beyond black gram has a chance of reaping a relative advantage over green gram.
In conclusion, pulses differ in their yield potentials and sowing date tremendously influence yield performance. If sowing has to be delayed, black gram has a relative advantage over green gram and may fit better in existing cropping sequences. Green gram is recommended $21^{\text {st }}$ March and black gram for $28^{\text {th }}$ March and beyond.

\section{Acknowledgement}

Authors are thankful to the Department of Agronomy, Faculty of Agriculture, Bidhan Chandra Krishi Viswavidyalaya, Nadia, West Bengal for providing all the necessary facilities for the successful conduct of the experiment.

\section{References}

Ali, R.I., Awan, T.H., Ahmad, M., Saleem, M.U., Akhtar M. 2012. Diversification of rice-based cropping systems to improve soil fertility, sustainable productivity and economics. J. Anim. Plant Sci., 22(1): 108-112.

CACP. https://cacp.dacnet.nic.in.

Chovatia, P.K., Ahlawat, R.P.S., Trivedi, S.J. 1993. Growth and yield of summer green gram as affected by different dates of sowing, rhizobium inoculation and levels of phosphorus. Indian Journal of Agronomy, 38: 492-494.

Dapaah, H.K., Mckenzie, B.A., Hill, G.D. 2000. Influence of sowing date and irrigation on the growth and yield of pinto beans (Phaseolus vulgaris) in a sub-humid temperate environment. Journal of Agricultural Science, 134: 33-43.

Das, S.K. 2017. Effect of phosphorus and sulphur on yield attributes, yield, nodulation and nutrient uptake of green gram [Vigna radiate (L.) wilczek]. Legume Research: An International Journal, 40(1): 138-143. 
Jackson, M.L. 1967. Soil Chemical Analysis. Prentice Hall of India Pvt. Ltd., New Delhi, pp. 498.

Khan, M.A., Baloch, M.S., Taj, I., Gandapur, I. 1999. Effect of phosphorous on the growth and yield of mungbean. Pak. J. Biol. Sci., 2(3):667-669

Ma, F., Na, X., Xu, T. 2016. Drought responses of three closely related Caragana species: Implication for their vicarious distribution. Ecology and Evolution, 6(9): 2763-2773.

Mohapatra, S.C., Patra, A.K., Senapati, S.C., Mishra A. 1996. Response of black gram (Phaseolus mungo L.) varieties to phosphorus. Crop Research, 11(2): 165168.

Okeleye, K.A. and Okelana, M.A.O. 1997. Effect of phosphorus fertilization on nodulation, growth and yield of cowpea (Vigna unguiculata) varieties. Indian J. Agric. Sci., 67(1): 10-12.

Poorter, H., Niklas, K.J., Reich, P.B., Oleksyn, J., Poot, P., Mommer, L. 2012. Biomass allocation to leaves, stems and roots: meta-analyses of interspecific variation and environmental control, New Phytologist, 193: 30-50.

Radford, P.J. 1967. Growth analysis formulae - their use and abuse. Crop Science, 7(3): 171-175.

Rahman, M.S., Eunus, M., Awal, M.A. 2002. Dry matter production and partitioning of mungbean (Vigna radiata L.) varieties as influenced by sowing date and planting method in summer. Bangladesh Journal of Training and Development, 15(1/2): 193-199.

Sadhukhan, I., Lohar, D., Pal, D.K. 2000. Pre monsoon season rainfall variability over gangetic West Bengal and its neighbourhood, India. Int. J. Climatol, 20: 1485-1493.

Samant, T.K. 2014. Evaluation of growth and yield parameters of green gram (Vigna radiata L.) Agric. Update, 9(3): 427430.

Sheoran, O.P., Tonk, D.S., Kaushik, L.S., Hasija, R.C., Pannu, RS. 1998. Statistical Software Package for Agricultural Research.

Singh, A.K., Singh, S.S., Prakash, V., Kumar, S., Dwivedi, S.K. 2015. Pulses Production in India: Present Status, Bottleneck and Way Forward. Journal of Agrisearch, 2(2): 75-83.

Singh, N. 2017. Pulses: An overview. Journal of Food Science and Technology, 54(4): 853

Singh, V.K., Sharma, B.B., Sahu, J.P. 2008. Effect of organic and inorganic sources of nutrients on urdbean productivity. Journal of Food Legumes, 21(3): 173173.

Tiwari, A.K., Shivhare, A.K. 2016. Pulses in India: Retrospect and Prospects. Director, Govt. of India, Ministry of Agri. \& Farmers Welfare, Directorate of Pulses Development, Vindhyachal Bhavan, Bhopal. pp. 23-25

Tiwari, B.K., Singh, N. 2012. Pulse chemistry and technology. Royal Society of Chemistry, Cambridge.

Wang, L., Huang, J., Luo, Y., Yao, Y., Zhao, Z. 2015. Changes in extremely hot summers over the global land area under various warming targets. Plos One, 10(6): e0130660.

\section{How to cite this article:}

Sritama Biswas, Ananya Chakraborty, Srijani Maji and Pintoo Bandopadhyay. 2019. Ecophysiology and Economics of Green Gram and Black Gram as Influenced by Sowing Dates in Tropical Summers. Int.J.Curr.Microbiol.App.Sci. 8(09): 431-439. doi: https://doi.org/10.20546/ijcmas.2019.809.052 